\title{
Midterm evaluation of echocardiographic examination, cardiac catheterization findings and surgical results of patients with congenitally corrected transposition of great arteries: A single center experience
}

\section{Konjenital düzeltilmiş transpozisyonlu hastaların ekokardiyografik, kardiyak kateterizasyon ve cerrahi sonuçlarının orta dönem değerlendirilmesi: Tek merkez deneyimi}

\author{
Mustafa Orhan BULUT, İlker Kemal YÜCEL, Şevket BALLI, Emine HEKİM YILMAZ, Ayhan ÇEVIK, \\ Ahmet ÇELEBI
}

Dr. Siyami Ersek Göğüs Kalp Damar Cerrahisi Hastanesi, İstanbul

\section{ABSTRACT}

\begin{abstract}
Congenitally corrected transposition of the great arteries (cc-TGA), is also defined as double discordance and ventricular inversion.

We conducted a retrospective evaluation of medical records of 79 patients diagnosed and followed-up with congenital transposition of great arteries between December 1993 and January 2014 at our pediatric cardiology department.

Of 79 patients included in the study, $46(58.2 \%)$ were male, mean age at diagnosis was $40 \pm 39.25$ months and the mean follow-up time was $56 \pm 39.4$ months. Thirteen $(16.5 \%)$ patients had atrial situs inversus. The most common concomitant abnormality was found to be ventricular septal defet $(29.1 \%)$. Fourty- five patients had pulmonary stenosis either in the form of valvular, subvalvular or both together. Twelve $(15.2 \%)$ patients had pulmonary atresia. Systemic atrioventricular valve (AV) regurgitation was present in $51(64.6 \%)$ patients, whereas $2(2.5 \%)$ patients had severe systemic AV valve regurgitation. Ebstein-like AV valve was detected in $5(6.3 \%)$ patients. Transcatheter interventions included ductal stent implantation $(n=5 ; 6.3 \%)$, left ventriculopulmonary artery conduit angioplasty $(\mathrm{n}=2 ; 2.5 \%), \mathrm{RV}-\mathrm{PA}$ conduit angioplasty $(\mathrm{n}=1 ; 1.3 \%)$ and pulmonary balloon valvuloplasty $(\mathrm{n}=2 ; 2.5 \%)$. Eleven $(13.9 \%)$ patients underwent interventional therapeutic cardiac catheterization. Glenn anastomosis was performed in $16(20.3 \%)$ patients. Nine (11.4\%) patients required a permanent pacemaker implantation.

Individualization of treatments and managements for the patients is of prognostic importance for these patients needing lifelong follow-up due to the large number of accompanying anomalies and different degrees of abnormalities in cc-TGA patients.
\end{abstract}

Keywords: Congenitally corrected transposition, pulmonary stenosıs, atrioventricular block

$\ddot{o z}$

Kongenital düzeltilmiş büyük arter transpozisyonu, atriyoventriküler, ventriküloarteryal diskordans olarak tanımlanır.

Aralık 1993-Ocak 2015 tarihleri arasında pediyatrik kardiyoloji bölümünde takip edilen 64 hasta retrospektif olarak değerlendirildi.

Çalı̧̧mamız 79 hastadan oluştu. Hastalarımızın $46(\% 58,2)$ 'sı erkek, ortalama tanı yaşı $40 \pm 39,25$ ay, ortalama takip süresi $56 \pm 39.4$ ay idi. On üç $(\% 16,5)$ hasta atriyal sitüs inversus idi. En sık eşlik eden anomali ventriküler septal defekt $(\% 29,1)$ idi. Kırk beş hastada valvular ve/veya subpulmoner stenoz vardı. Hastaların \% 15,2'si pulmoner atrezik idi. Sistemik atriyoventriküler kapak yetersizliği 2 hastada ağır idi. Beş hastada $(\% 6,3)$ Ebstein benzeri triküspid kapak yapısı belirlendi. Beş hastada ductal stent, 2 hastada sol ventrikül-pulmoner arter (PA) konduit anjiyoplasti, 1 hastada sağ ventrikül-PA konduit anjiyoplasti, 2 hastada pulmoner balon anjiyoplasti uygulandı. On altı hastaya Glenn anastomozu uygulandı. Hastaların \%11,4'ünde kalıcı pil implantasyonu gerektiren atriyoventriküler tam blok saptand.

Bu hastalarda farkh derecelerde anomalilerin eşlik etmesi nedeniyle ömür boyu takip ve tedavi prognostik önemlidir.

Anahtar kelimeler: Konjenital düzeltilmiş transpozisyon, pulmoner stenoz, atrıventriküler blok
Alındığı tarih: 14.12 .2016

Kabul tarihi: 30.04 .2017

Yazışma adresi: Doç. Dr. Şevket Ballı, Dr. Siyami Ersek Göğüs Kalp Damar Cerrahisi Hastanesi, Kadıköy, 34660, İstanbul

e-mail: drsevketballi@hotmail.com 


\section{INTRODUCTION}

Congenitally corrected transposition of the great arteries (cc-TGA), also termed as double discordance and ventricular inversion or physiologically corrected transposition of the great arteries, is a rare defect characterized by the combination of atrioventricular and ventriculoarterial discordance, which comprises about $0.5 \%$ of all congenital cardiac anomalies ${ }^{(1)}$. There is a heterogeneous group of patients and highly variable clinical course associated with the presence and severity of accompanying abnormalities such as ventricular septal defect (VSD), pulmonary stenosis (PS)/atresia, Ebstein-like malformation of the tricuspid valve (2). Long-term survival and, if possible, morphological right ventricular dysfunction and tricuspid regurgitation counter-acting the systemic circulation are important prognostic determinants in these patients ${ }^{(3-5)}$. Surgical procedures include conventional repair (atrial septal defect and VSD closure, elimination of PS, isolated tricuspid valve repair), anatomic repair (double switch operation; atrial switch and arterial switch), and Fontan-type repair options ${ }^{(19)}$. Due to the negative consequences of conventional surgery in which morphologic right ventricle will be the systemic ventricle, as an alternative double switch procedure which restores morphologic left ventricle to the systemic circulation emerged. In patients with congenital corrected transposition of the great arteries, the possibility of congenital or postoperative AV (atrioventricular) block and the tachyarrhythmia is increased due to the conduction system abnormalities and potential instability. A lifelong follow-up is required because the possibility of the development of complete AV block after the diagnosis is estimated to be $2 \%$ per annum ${ }^{(7,8)}$.

In this study, we aimed to present our experiences by conducting retrospective analysis of the echocardiographic findings, cardiac catheterization findings of those with an indication, need for a permanent pacemaker, and surgical/transcatheter interventional procedures among cc-TGA patients diagnosed and followed-up in our pediatric cardiology and cardiac surgery departments.

\section{METHODS}

Patient group: We conducted retrospective evaluation of medical records of 64 patients diagnosed and followed-up with congenital transposition of great arteries between December 1993 and January 2013 at our pediatric cardiology department. The study was approved by the local ethics committee. Patients who did not participate at a regular follow-up were excluded from the study. We analyzed the demographic data and transthoracic echocardiographic findings of all patients, the records of 15 patients with an indication for cardiac catheterization, the records of medical treatment and surgical treatment, and follow-up records of patients with an indication of pacemaker placement.

\section{Transthoracic Echocardiography}

The diagnosis of cc-TGA was confirmed by the presence of a combination of AV discordance and VA discordance. We used GE Philips IE33 cardiovascular ultrasound systems (Philips Medical Systems, Andover, MD. USA) with a 2-D, M-mode and color Doppler data. We performed segmental analysis of visceral and atrial situs, atrioventricular and ventriculoarterial (VA) connections, atrioventricular valves, interatrial septum (IAS) and interventricular septum (IVS), the relationships of the great arteries and accompanying pathologies.

\section{Cardiac Catheterization}

A Philips Advantx LC/LP device (GE Healthcare, USA) was used for invasive measurements and transcatheter interventions.

\section{Statistical analysis:}

Data analysis was performed with the help of SPSS for Windows, version 15 (SPSS Inc., Chicago, IL, United States). Continuous variables were tabulated in the form of mean ( \pm standard deviation) or median, as appropriate (range). Nominal data distribution was described as absolute number (percentage). Differences between groups were compared by Student's t-test or the Mann-Whitney U test depending on the distribution. Nominal data were analyzed 
by the chi-square test or Fisher's exact test as appropriate. A p-value lower than 0.05 was the threshold for statistical significance.

\section{RESULTS}

Of 79 patients included in the study, 46 (58.2\%) were male, and mean age at diagnosis was $40 \pm 44.25$ months and the mean follow-up period was $56 \pm 39.4$ months. Thirteen $(16.5 \%)$ patients had atrial situs inversus. The most common great artery relationship was found to be L-TGA in 58 (73.4\%) patients, whereas D-TGA was found in $15(19 \%)$ patients. The most common concomitant abnormality was found to be large inlet to outlet VSD in 23 patients (29.1\%). Forty- five patients had pulmonary stenosis either in the form of valvular, subvalvular or in combination. Twelve $(15.2 \%)$ patients had pulmonary atresia. According to initial diagnosis 42 (\%53.2) patients had VSD with pulmonary stenosis. Systemic AV valve regurgitation was present in $51(64.6 \%)$ patients, whereas $2(2.5 \%)$ patients had severe systemic AV valve regurgitation. Ebstein-like AV valve was detected in $5(6.3 \%)$ patients. Six $(7.6 \%)$ patients had no associated cardiac anomalies. Fourteen $(17.7 \%)$ patients had pulmonary hypertension. Forty-five $(56.9 \%)$ patients underwent surgical intervention. Conventional surgery repair were applied in 11 patients. Eleven (13.9\%) patients underwent interventional therapeutic cardiac catheterization. Nine $(11.4 \%)$ patients required a permanent pacemaker implantation, of whom 6 patients developed postoperative AV block (Table 1). Echocardiographic findings of the patients are shown in Table 2. Diagnostic cardiac

Table 1. Anthropometric, structural, hemodynamic values.

\begin{tabular}{lc}
\hline & $\mathbf{N}=\mathbf{7 9}$ \\
\hline Gender (male/female) & $46 / 33$ \\
Weight (kg, mean \pm SD, min-max & $13.1 \pm 10.0(2.8-49)$ \\
Height (cm, mean \pm SD, min-max & $86.8 \pm 29.3(47-158)$ \\
Atrial situs (solitus/inversus) & $66 / 13$ \\
Dextrocardia/levocardia & $26 / 53$ \\
Pulmonary hypertension & 14 \\
Transcatheter intervention & 11 \\
The presence of pace maker & 9 \\
Surgical treatment & 45 \\
\hline
\end{tabular}

catheterization findings are presented in Table 3. Mean PAP (pulmonary artery pressure) was $30 \pm 25.71$ mmHg, mean PAP systolic was 43.14 \pm 35.76 (11-107) $\mathrm{mmHg}$, mean $\mathrm{Rp}$ (pulmonary vascular resistance) was 7.7 \pm 5.3 (2.1-16.2) Wood $\mathrm{U} / \mathrm{m}^{2}$, and mean $\mathrm{Rp} / \mathrm{Rs}$ (systemic vascular resistance) was $0.47 \pm 0.21(0.23$ $0.64)$. Palliative and definitive surgical and transcatheter interventions of the patients are presented in

Table 2. Echocardiographic findings of the patients.

\begin{tabular}{|c|c|c|}
\hline Variables & $\mathbf{n}$ & $\%$ \\
\hline L-TGA & 58 & 73.4 \\
\hline D-TGA & 15 & 19 \\
\hline Side by side & 1 & 1.3 \\
\hline Anteroposterior relationship & 1 & 1.3 \\
\hline \multicolumn{3}{|l|}{ VSD Location } \\
\hline None & 9 & 11.4 \\
\hline Large Inlet to Outlet & 23 & 29.1 \\
\hline Inlet to subpulmonic & 17 & 21.5 \\
\hline Doubly committed & 3 & 3.8 \\
\hline Bulboventricular foramen (non-restrictive) & 2 & 2.5 \\
\hline Inlet remote large & 4 & 5.1 \\
\hline Inlet muscular - outlet muscular & 3 & 3.8 \\
\hline Operated residual VSD & 6 & 7.6 \\
\hline Perimembraneous inlet small & 6 & 7.6 \\
\hline Subpulmonic & 5 & 6.3 \\
\hline \multicolumn{3}{|l|}{ Pulmonary Stenosis } \\
\hline None & 22 & 27.8 \\
\hline At the level of atresia & 12 & 15.2 \\
\hline Valvular & 12 & 15.2 \\
\hline Valvular and subvalvular & 18 & 22.8 \\
\hline Conduit stenosis & 6 & 7.6 \\
\hline Subvalvular & 8 & 10.1 \\
\hline \multicolumn{3}{|l|}{ Systemic AV Valve Regurgitation } \\
\hline None & 28 & 35.4 \\
\hline Mild & 33 & 41.8 \\
\hline Moderate & 16 & 20.3 \\
\hline Severe & 2 & 2.5 \\
\hline \multicolumn{3}{|l|}{ Pulmonary AV Valve Regurgitation } \\
\hline None & 47 & 59.5 \\
\hline Mild & 22 & 27.8 \\
\hline Moderate & 9 & 11.4 \\
\hline \multicolumn{3}{|l|}{ Pulmonary hypertension } \\
\hline None & 65 & 82.3 \\
\hline Mild & 4 & 5.1 \\
\hline Systemic & 10 & 12.7 \\
\hline \multicolumn{3}{|l|}{ Other Accompanying Anomalies } \\
\hline Ebstein like AV valve & 5 & 6.3 \\
\hline LPA hypoplasia & 3 & 3.8 \\
\hline The absence of native pulmonary artery & 1 & 1.3 \\
\hline Right AV valve straddling & 2 & 2.5 \\
\hline RV hypoplasia & 2 & 2.5 \\
\hline LV noncompaction & 2 & 2.5 \\
\hline Coarctation of aorta & 1 & 1.3 \\
\hline Criss cross heart & 1 & 1.3 \\
\hline Left-sided juxtaposition of atrial appendage & 1 & 1.3 \\
\hline
\end{tabular}


Table 4. Forty-three (43\%) patients were found to be non-eligible for surgical treatment. Glenn anastomosis was performed in 16(20.3\%) patients. Transcatheter interventions included ductal stent implantation $(n=5$; $6.3 \%)$, LV (left ventricle)-PA (pulmonary artery) con-

Table 3. Cardiac catheterization findings.

\begin{tabular}{lccc}
\hline & mean \pm SD & median & min-max \\
\hline RAP $(\mathrm{mmHg})$ & $6.84 \pm 3.23$ & 7.0 & $3-12$ \\
LAP $(\mathrm{mmHg})$ & $13.44 \pm 8.06$ & 11 & $6-14$ \\
PAP systolic $(\mathrm{mmHg})$ & $43.14 \pm 35.76$ & 22 & $11-107$ \\
PAP diastolic $(\mathrm{mmHg})$ & $22.07 \pm 21.34$ & 13 & $2-60$ \\
PAP mean $(\mathrm{mmHg})$ & $30 \pm 25.71$ & 17 & $7-82$ \\
SP (systolic) $(\mathrm{mmHg})$ & $100.1 \pm 16.16$ & 103 & $64-130$ \\
SP (diastolic) $(\mathrm{mmHg})$ & $60.84 \pm 10.62$ & 61 & $45-78$ \\
Aortic $(\mathrm{mean})(\mathrm{mmHg})$ & $72.76 \pm 8.95$ & 72 & $62-93$ \\
Qp $\left(1 / \mathrm{min} / \mathrm{m}^{2}\right)$ & $5.1 \pm 2.24$ & 4.4 & $3.30-8.30$ \\
Qs $\left(1 / \mathrm{min} / \mathrm{m}^{2}\right)$ & $2.93 \pm 0.56$ & 3.05 & $2.80-4$ \\
Qp/Qs & $1.7 \pm 1.1$ & 1.4 & $1-2.91$ \\
Rp (Wood $\left.\mathrm{U} / \mathrm{m}^{2}\right)$ & $7.7 \pm 5.3$ & 6.1 & $2.1-16.2$ \\
Rs (Wood U/m $\left.{ }^{2}\right)$ & $18.9 \pm 5.6$ & 15.7 & $15.6-25.5$ \\
Rp/Rs & $0.47 \pm 0.21$ & 0.56 & $0.23-0.64$ \\
\end{tabular}

Abbreviations: RAP, right atrial pressure; LAP, left atrial pressure, PAP, pulmonary artery pressure; PAP, pulmonary artery pressure; $S P$, systemic pressure, Qp: pulmonary flow, Qs: systemic flow, Rp: pulmonary resistance, Rs: systemic resistance.

Table 4. Surgical and transcatheter interventions.

\begin{tabular}{lcc}
\hline Variables & n & \% \\
\hline Operation & 34 & 43 \\
None & 5 & 6.3 \\
VSD closure & 1 & 1.3 \\
Double switch & 1 & 1.3 \\
LV-PA homozygous interposition & 16 & 20.3 \\
Glenn anastomosis & 1 & 1.3 \\
Rastelli-hemimustard-Glenn & 6 & 7.6 \\
VSD closure-LV-PA conduit & 3 & 3.8 \\
Fontan operation -Lateral tunnel & 1 & 1.3 \\
Coarctation repair and pulmonary banding & 4 & 5.1 \\
Fontan operation - Extracardiac & 5 & 6.3 \\
VSD closure and pulmonary banding & & \\
Transcatheter intervention & 65 & 82.2 \\
None & 5 & 6.3 \\
Ductal stent implantation & 2 & 2.5 \\
LV-PA conduit angioplasty & 1 & 1.3 \\
RV-PA conduit angioplasty & 1 & 1.3 \\
Atrial septostomy & 2 & 2.5 \\
Pulmonary balloon valvuloplasty & 1 & 1.3 \\
Interventional Closure of Fontan fenestration & 1 & 1.3 \\
Transcatheter dilatation of BT shunt & 1 & 1.3 \\
Percutan pulmonary valv replacement & & \\
\hline & & \\
\hline
\end{tabular}

Abbreviations: VSD, ventricular septal defect; $L V$ : left ventricle, $R V$ : right ventricle, PA: pulmonary artery, BT: Blalock-Taussig. duit angioplasty ( $\mathrm{n}=2 ; 2.5 \%), \mathrm{RV}$ (right ventricle)-PA conduit angioplasty $(\mathrm{n}=1 ; 1.3 \%)$ and pulmonary balloon valvuloplasty $(\mathrm{n}=2 ; 2.5 \%)$ (Table 4$)$.

\section{DISCUSSION}

In this study the data of demographic, echocardiographic and catheterization findings of 79 patients with cc-TGA, and the experience of a single center on surgery and interventional cardiac catheterization were analyzed retrospectively. Several studies have estimated the incidence as 2.6 to 8.6 per 1000 live births ${ }^{(1,9)}$. A variable clinical course and long-term follow-up results have been reported in cc-TGA patients, which are heterogeneous group of patients because of having a rare anomaly and the presence of numerous accompanying anomalies ${ }^{(9,11)}$. In our study, a male predominance was reported with a rate of $58.2 \%$, which is consistent with the literature. In the studies, the age at diagnosis was found to be in a wide range from 1 day to 80 years based on accompanying abnormalities ${ }^{(10)}$. In our study, the median age at diagnosis was 53.7 months with a range of 1 day to 28 years. Although situs solitus was detected in most cases, the incidence of situs abnormalities was reported to be $34 \%$ in pediatric series, and the patients with situs inversus presented with fewer Ebstein-like malformations, spontaneous complete AV block and long-term complications ${ }^{(11)}$. In our patient group $79.7 \%$ of the patients had situs solitus. No significant difference was found between the situs solitus and situs inversus groups in terms of accompanying anomalies, treatment regimen and development of $\mathrm{AV}$ block ( $p>0.05)$. The presence of anomalies in patients with cc-TGA and detection and management of these anomalies are important factors determining longterm survival. In our study, 6 (7.6\%) patients had no associated cardiac anomalies, which is similar to the rate of $9 \%$ in the series reported by Lundstrom et al ${ }^{(12)}$. The most common concomitant anatomic pathologies were reported as VSD and pulmonary stenosis or pulmonary atresia with incidence rates of $70-84 \%$ and 24 to $76 \%$, respectively ${ }^{(10,12-15)}$. In our study, $88.6 \%$ of the patients had VSD (most frequently large inlet to outlet VSD). While pulmonary stenosis was 
not detected in $27.8 \%$ of the patients, the rest had pulmonary stenosis and pulmonary atresia (15.2\%). Forty- two (\%53.2) patients had VSD with pulmonary stenosis. Systemic AV valve abnormalities (dysplasia, straddling, Ebstein-like malformation) alone or in combination with valve regurgitation have been reported at different rates in various studies $(7,10,12,14,15)$. The incidence of Ebstein-like malformation has been reported as $76 \%$ by Allwork et al and $0.3 \%$ by Silverman et al, and this difference between incidence rates may be due to the different interpretation of the pathology reports ${ }^{(10,16)}$. In our study, systemic AV valve straddling was found in $3(3.8 \%)$ patients and Ebstein-like malformation in $5(6.3 \%)$ patients.

The incidence of complete AV block has been reported to range between 12 and 33 percent ${ }^{(7,8)}$. In our study, 9 (11.4\%) patients developed complete AV block and required permanent pacemaker implantation, and 6 of them had also postoperative AV block. Daliento et al. ${ }^{(8)}$ have documented that first-and second-degree AV blocks progress to complete AV block due to the fibrosis of the conduction system with increasing age. Accordingly, our cases are periodically followed-up for AV conduction disorders. Other accompanying rhythm disorders have been reported as supraventricular tachycardia, atrial flutter, atrial fibrillation, Wolff-Parkinson-White syndrome, ventricular ectopia and exercise-induced ventricular tachycardia ${ }^{(8,11,17)}$.

Today, cardiac catheterization is applied for diagnostic purposes in patients with increased pulmonary vascular resistance that is non-assessable with noninvasive methods, for instance when pulmonary vasodilator response is evaluated, in severe systemic valve regurgitation, and when aortopulmonary collateral or abnormal coronary anatomy is suspected. As in our patient group, it is implemented to treat conduit stenosis by percutaneous intervention in patients underwent surgery or for device occlusion of Fontan fenestration. In these patients, before cardiac catheterization equipment should be ready for temporary or permanent pacemaker implantation because of anteriorly located AV node and fragile conduction system ${ }^{(20)}$.

Presence of clinically important accompanying abnormalities such as ventricular septal defect (VSD), pulmonary stenosis (PS)/atresia can necessitate surgical intervention. Surgical procedures include conventional repair (ASD and VSD closure, elimination of PS, isolated tricuspid valve repair), anatomic repair (double switch operation; atrial switch and arterial switch), and Fontan-type repair options ${ }^{(19)}$. As the long term result of each alternative procedure is not satisfactory, timing and mode of surgical method must be carefully analyzed for each patient. Until recently conventional physiological repair of accompanying anomalies (VSD closure, LV-PA conduit for pulmonary atresia and stenosis, etc.) were preferred. The persistence of the morphologic right ventricle as systemic ventricle had resulted in progressive tricuspid regurgitation and ended up with systemic ventricular dysfunction. In terms of long-term results, it was disappointing ${ }^{(1,6,20)}$. Lundstom et al. reported premature deaths in 11 out of 51 cases. In addition, Hraska et al. reported 10 year-survival rate as $70 \%$, whereas Yeh et al reported 20 year survival rate as $48 \%$ and in $56 \%$ of the cases the need for reoperation arised ${ }^{(19,20)}$. Ebstein's malformation of the tricuspid valve and systemic ventricular dysfunction are the most important risk factors in these patients, so implementation of surgical approaches alternative to the conventional repair is important for the long-term prognosis of these patients. We applied conventional surgical repair in 11 patients without these risk factors. One of these patients was monitored for 38 months with diagnoses of mild insufficiency of bilateral atrioventricular valves and myocardial noncompaction, who was clinically stable with an oxygen saturation level around 90 percent. The second patient (who underwent balloon angioplasty for severe conduit stenosis) had mild stenosis in the LV-PA conduit and mild systemic valve regurgitation, and was monitored with clinically stable status. The third patient had mild stenosis in the LV-PA conduit and moderate systemic $\mathrm{AV}$ valve regurgitation. The 4 th and the 5th patient had mild systemic AV valve regurgitation, and moderate systemic AV valve regurgitation (6. and 7. patients), AV valve regurgitation ( $8^{\text {th }}$ patient), th severe stenosis in the RV-PA conduit (balloon angioplasty was performed for severe conduit stenosis), 
and mild systemic AV valve regurgitation ( $9^{\text {th }}$ patient), moderate systemic AV valve regurgitation and systolic dysfunction (postoperative follow-up period of 42 months) ( $10^{\text {th }}$ patient), and the $11^{\text {th }}$ patient developed progressive severe systemic AV valve regurgitation at the month 62 of the follow-up despite systemic AV valve repair.

Surgical modalities that focus on switching the morphological left ventricle from pulmonary circulation to the systemic circulation are anatomically corrective surgical procedures and can positively affect the long-term prognosis of these patients. Double switch procedure is usually performed during the first 6-8 months of life in patients with adequate LV hemodynamics, who do not have any significant left ventricular outflow tract obstruction (LVOTO) and whose pulmonary valve is appropriate to be a neoaortic valve ${ }^{(21)}$.

In patients with VSD and outflow obstruction, the combination of Senning and Rastelli procedures is preferred as surgical approaches. Shin'oka et al. ${ }^{(19)}$ have reported 15 year survival rate after 84 anatomical correction surgeries as $75 \%$ for double switch and $80 \%$ for Rastelli-Senning/Mustard procedures. When postoperative morbidity and mortality in patients undergoing anatomic correction over the short and intermediate-term outcomes were evaluated, it was found that Senning/arterial switch operations produced better outcomes than those of Senning/Rastelli operations, though long-term follow-up results have not been reported ${ }^{(23)}$. In our patient group, one patient underwent the combination of Senning and Rastelli procedure and one patient underwent mustard + Rastelli + Glenn combination. During the follow-up of 136 months of our patient who had undergonen combined Senning and Rastelli procedures, we detected mild conduit stenosis (balloon angioplasty was performed once for severe conduit stenosis), mild insufficiency in bilateral atrioventricular valves, and global systolic dysfunction at the $120^{\text {th }}$ month of the follow-up period. The patient undergoing combined Mustard-Rastelli-Glenn operation was clinically stable with mild AV valve regurgitation, mild conduit stenosis and $\mathrm{O}_{2}$ saturation of $84-86 \%$ at the month 98 of the ongoing follow-up.
Unfortunately, double switch procedure does not return everything to normal. Intraoperative risks are higher in double switch than the classical repair. Each component of double switch procedure has its own potential risks. Atrial baffling procedures have the risk of obstruction and leak, and if patients followed long enough it may end up with atrial arrhythmias. After arterial switch operation late coronary arterial obstruction may develop as a result of transfer of coronary arteries. The Rastelli operation itself has its own risks like subaortic stenosis, ventricular dysfunction and conduction system problems ${ }^{(25)}$. A high risk anatomic repair that we were inexperienced is preferable to classical or single ventricular repair ${ }^{(31)}$. Although significant improvements have been reported in the right ventricle and tricuspid valve functions after the anatomical correction, long-term follow-up of these patients is particularly important for the early detection of progressive left ventricular systolic dysfunction in the late phase ${ }^{(26,27)}$. However, further randomized clinical studies are needed to compare late outcomes of surgical approaches targeting physiological and anatomical correction.

One of the major factors associated with increased morbidity and mortality in cc-TGA patients is tricuspid regurgitation (TR). It has been noticed that after conventional repair TR increases. ccTGA patients with PS have better long term results than simple ccTGA ones. Pulmonary artery banding increases morphologic LV (mLV)/morphologic RV (mRV) pressure ratio beside maintaining a conditioned $\mathrm{mLV}$. As a result, septum will shift to right which will improve tricuspid competence. Reduction in TR is the probable factor that will prevent $\mathrm{mRV}$ dilatation and dysfunction. Early prophylactic pulmonary banding especially before puberty is advised as beyond infant age group the result of banding will be hypertrophy rather than hyperplasia and this may end up with $\mathrm{mLV}$ dysfunction which is a poor prognostic factor. Mild, dilatable pulmonary banding is offered when ccTGA is diagnosed before 6 months' age, after this age group it is offered when significant TR or mRV dysfunction is noticed ${ }^{(22,35)}$. Kollars et al. ${ }^{(34)}$ performed pulmonary artery banding with the aim of increasing LV/RV pressure ratio. This attempt resulted in 
a less spherical right ventricle, improvement in coaptation of tricuspid valve and as a consequence remission in TR. As a result they suggested pulmonary artery banding itself may be an alternative for long term palliation ${ }^{(22,35)}$. Winlaw et al. ${ }^{(36)}$ reported their results of pulmonary artery banding applied to patients whose systemic ventricle is RV. Sixteen of 32 banded patients achieved successful anatomic repair, 8 of them persisted with palliative banding and 7 patients underwent debanding, and one patient died.

In our patient group, 6 patients underwent pulmonary artery banding. All of them are still alive. During follow up none of the patient's functional status and RV function detoriated. In three infants pulmonary banding performed with the aim of preserving a trained LV and preventing RV dilatation and TR. In three of them patients were older with TR, dilated spheric RV. Among these 6 patients TR, RV function, RV dilatation showed no significant deterioration and all persisted with palliative banding.

In patients who require complex biventricular repair or not candidates for biventricular repair, it has been reported that Fontan operation had more successful results ${ }^{(18,24)}$. Another treatment option for this type of patients is one-and-one half ventricle repair between Fontan circulation and classic conventional physiological surgical repair ${ }^{(25)}$. This repair can be performed in patients with cc-TGA and PS whether they have VSD or not, and candidates may be selected from patient populations who are considered suboptimal for anatomical repair or conventional repair. There was no patient considered suboptimal for one-and-one half ventricle repair in our study. Glenn anastomosis with antegrade pulmonary blood flow may be an ideal definitive palliation in patients considered suboptimal candidates for a Fontan circulation or those who might meet the Fontan criteria in the future ${ }^{(29)}$. As Glenn anastomosis unloaded the morphologic left ventricle, the consequence was a decrease in the degree of tricuspid valve insufficiency and improvement in the right ventricular function. In our patient group, 9 patients underwent Glenn operation with antegrade pulmonary blood flow, and 1 patient underwent classical Glenn operation, and 6 patients received bidirectional Glenn operation.
According to our experience Glenn anastomosis with antegrade pulmonary blood flow is suitable strategy for definitive palliation, particularly in cc-TGA patients considered high risk candidates for Fontan circulation. Therefore, instead of performing complex biventricular repair procedures, Glenn anastomosis with antegrade pulmonary blood flow may be performed. Three of our patients received lateral tunnel Fontan operation and 4 patients underwent extracardiac Fontan operation. In one patient who underwent Fontan operation, we observed edema and decreased saturation for 3 years of follow-up, therefore, we performed percutaneous closure of Fontan fenestrations with transcatheter device, so the patient's complaints decreased and the oxygen saturation increased to $97 \%$. No other complication occurred in the patients who received Fontan operation during the follow-up.

Among 79 patients 34 (43.1\%) of them had not been operated before, and cyanosis, congestive heart failure resistant to medical therapy, deteriorating right ventricle or TR causing right ventricular dilatation were not detected. Presence of accompanying abnormalities is not an absolute indication for surgery as long term results in patients with mild to moderate LVOT obstruction are better than the ones without stenosis. At first necessity, than time and type of procedure should be decided according to postoperative short term morbidity and mortality, and long term results.

Pulmonary vascular disease may complicate congenital heart disease including cc-TGA. Surgical repair is indicated when PVRI is not $>10$ Wum 2 and when pulmonary-to-systemic flow ratio is at least 2:1 ${ }^{(32)}$. In our study, $10(15.6 \%)$ patients diagnosed as systemic $\mathrm{PH}$, and 4 (5.1\%) patients as mild $\mathrm{PH}$ according to echocardiographic evaluation. Cardiac catheterization was not applied to all of them.

\section{CONCLUSION}

Individualization of treatments and managements is of prognostic importance for these patients needing lifelong follow-up due to the large number of accompanying anomalies and different degrees of abnorma- 
lities in cc-TGA patients.

Even if there is no accompanying defect, cc-TGA is associated with poor survival rates due to $\mathrm{AV}$ valve regurgitation and systemic ventricular failure. In the presence of accompanying defects, the conventional repair may be complicated by the early or late dysfunction of tricuspid valve and systemic ventricle, depending on the tricuspid valve and the right ventricle remaining in the systemic circulation. Although better long-term outcomes are expected after anatomic repair, further studies with long-term monitoring are needed to confirm this assumption .

Limitations of the Study: The most obvious limitation of the study is that it does not allow a comparison of different treatment strategies due to the categorization of our patients into several subgroups, as the cc-TGA patient population is a heterogeneous group of patients. The lack of data on long-term follow-up findings in this patient group is another limitation.

\section{REFERENCES}

1. Hornung TS, Calder L. Congenitally corrected transposition of the great arteries. Heart 2010;96:1154-61.

https://doi.org/10.1136/hrt.2008.150532

2. Rutledge JM, Nihill MR, Fraser CD, Smith OE, McMahon CJ, Bezold LI. Outcome of 121 patients with congenitally corrected transposition of the great arteries. Pediatr Cardiol 2002;23:137-45.

https://doi.org/10.1007/s00246-001-0037-8

3. Huhta JC, Danielson GK, Ritter DG, Ilstrup DM. Survival in atrioventricular discordance. Pediatr Cardiol 1985;6:57-60. https://doi.org/10.1007/BF02282738

4. Presbitero P, Somerville J, Rabajoli F, Stone S, Conte MR. Corrected transposition of the great arteries without associated defects in adult patients: clinical profile and follow up. $\mathrm{Br}$ Heart J 1995;74:57-9. https://doi.org/10.1136/hrt.74.1.57

5. Hornung TS, Bernard EJ, Celermajer DS, Jaeggi E, HowmanGiles RB, Chard RB, Hawker RE. Right ventricular dysfunction in congenitally corrected transposition of the great arteries. Am J Cardiol 1999;84:1116-9. https://doi.org/10.1016/S0002-9149(99)00516-0

6. Shin'oka T, Kurosawa H, Imai Y, Aoki M, Ishiyama M, Sakamoto $\mathrm{T}$ et al.Outcomes of definitive surgical repair for congenitally corrected transposition of the great arteries or double outlet right ventricle with discordant atrioventricular connections: risk analyses in 189 patients. J Thorac Cardiovasc Surg 2007;133:1318-28.

https://doi.org/10.1016/j.jtcvs.2006.11.063

7. Huhta JC, Maloney JD, Ritter DG, Ilstrup DM, Feldt RH. Complete atrioventricular block in patients with atrioventricular discordance. Circulation 1983;67:1374-7.
https://doi.org/10.1161/01.CIR.67.6.1374

8. Daliento L, Corrado D, Buja G, John N, Nava A, Thiene G. Rhythm and conduction disturbances in isolated, congenitally corrected transposition of the great arteries. Am J Cardiol 1986;58:314-8. https://doi.org/10.1016/0002-9149(86)90069-X

9. Fyler DC, Buckley LP, Hellenbrand WE, Cohn HE. Report of the New England regional infant cardiac program. Pediatrics 1980;65:377-461.

10. Allwork SP, Bentall HH, Becker AE. Congenitally corrected transposition of the great arteries: morphologic study of 32 cases. Am J Cardiol 1976;38:910-23. https://doi.org/10.1016/0002-9149(76)90804-3

11. Oliver JM, Gallego P, Gonzalez AE, Sanchez-Recalde A, Brett M, Polo L et al. Comparison of outcomes in adults with congenitally corrected transposition with situs inversus versus situs solitus. Am J Cardiol 2012;110:1687-91. https://doi.org/10.1016/j.amjcard.2012.07.039

12. Lundstrom U, Bull C, Wyse RKH, Somerville J. The natural and 'unnatural' history of congenitally corrected transposition. Am J Cardiol 1990;65:1222-9. https://doi.org/10.1016/0002-9149(90)90978-A

13. Bjarke BB, Kidd BSL. Congenitally corrected transposition of the great arteries. Acta Pediatr Scand 1976:153-60

14. Metcalfe J, Sommerville J. Surgical repair of lesions associated with corrected transposition. Br Heart J 1983;50:47682.

https://doi.org/10.1136/hrt.50.5.476

15. McGrath LB, Kirklin JW, Blackstone EH, Pacifico AD, Kirklin JK, Bargeron LM. Death and other events after cardiac repair in discordant atrioventricular connection. $J$ Thorac Cardiovasc Surg 1985;90:711-28.

16. Silverman NH, Gerlis LM, Horowitz ES, Siew YH, Neches WH, Anderson RH. Pathologic elucidation of the echocardiographic features of Ebstein's malformation of the morphologically tricuspid valve in discordant atrioventricular connections. Am J Cardiol 1995;76:1277-83. https://doi.org/10.1016/S0002-9149(99)80356-7

17. Almahmeed W, Haykowski M, Boone J, Kavanagh-Gray D, Human D, Macdonald I. Congenitally corrected transposition of the great arteries and exercise-induced ventricular tachycardia. Can J Cardiol 1996;12:526-8.

18. Graham TP Jr, Bernard YD, Mellen BG, Celermajer D, Baumgartner $\mathrm{H}$, Cetta $\mathrm{F}$ et al. Long-term outcome in congenitally corrected transposition of the great arteries: a multiinstitutional study. J Am Coll Cardiol 2000;36:55-61. https://doi.org/10.1016/S0735-1097(00)00682-3

19. Hraska V, Duncan BW, Mayer JE Jr, Freed M, del Nido PJ, Jonas RA. Long-term outcome of surgically treated patients with corrected transposition of the great arteries. J Thorac Cardiovasc Surg 2005;129:182-91. https://doi.org/10.1016/j.jtcvs.2004.02.046

20. Yeh T Jr, Connelly MS, Coles JG, et al. Atrioventricular discordance: results of repair in 127 patients. J Thorac Cardiovasc Surg 1999;117:1190-1203. https://doi.org/10.1016/S0022-5223(99)70259-X

21. Devaney EJ, Bove EL. Pediatric Cardiac Surgery, 4th edition: Wiley Blackwell, 2013.

22. Metton O, Gaudin R, Ou P, Gerelli S, Mussa S, Sidi D, Vouhé P, Raisky O. Early prophylactic pulmonary artery banding in isolated congenitally corrected transposition of the great arteries. Eur J Cardiothorac Surg 2010;38:728-34. https://doi.org/10.1016/j.ejcts.2010.03.065

23. Gaies MG, Goldberg CS, Ohye RG, Devaney EJ, Hirsch JC, 
Bove EL. Early and intermediate outcome after anatomic repair of congenitally corrected transposition of the great arteries. Ann Thorac Surg 2009;88:1952-60. https://doi.org/10.1016/j.athoracsur.2009.08.014

24. Sharma R, Talwar S, Marwah A, Shah S, Maheshwari S, Suresh $\mathrm{P}$ et al. Anatomic repair for congenitally corrected transposition of the great arteries. J Thorac Cardiovasc Surg 2009; 137:404-12. https://doi.org/10.1016/j.jtcvs.2008.09.048

25. Backer CL, Stewart RD, Mavroudis C. The classical and the one-and-a-half ventricular options for surgical repair in patients with discordant atrioventricular connections. Cardiol Young 2006;3:91-6. https://doi.org/10.1017/S1047951106000801

26. Duncan BW, Mee RB, Mesia CI, Qureshi A, Rosenthal GL et al. Results of the double switch operation for congenitally corrected transposition of the great arteries. Eur $J$ Cardiothorac Surg 2003;24:11-9. https://doi.org/10.1016/S1010-7940(03)00189-1

27. Bautista-Hernandez V, Marx GR, Gauvreau K, Mayer JE Jr, Cecchin F, del Nido PJ. Determinants of left ventricular dysfunction after anatomic repair of congenitally corrected transposition of the great arteries. Ann Thorac Surg 2006;82:2059-65. https://doi.org/10.1016/j.athoracsur.2006.06.045

28. Alghamdi AA, McCrindle BW, Van Arsdell GS. De León LE, Mery CM, Verm RA et al. Mid-Term Outcomes in Patients with Congenitally Corrected Transposition of the Great Arteries: A Single Center Experience. J Am Coll Surg 2017;224(4):707-715. https://doi.org/10.1016/j.jamcollsurg.2016.12.029

29. Calvaruso DF, Rubino A, Ocello S, Salviato N, Guardì D, Petruccelli DF et al. Bidirectional Glenn and antegrade pulmonary blood flow: temporary or definitive palliation? Ann Thorac Surg 2008;85:1389-95. https://doi.org/10.1016/j.athoracsur.2008.01.013

30. Van Slooten YJ, Elzenga NJ, Waterbolk TW, van Melle JP, Berger RM, Ebels T. The effect of additional pulmonary blood flow on timing of the total cavopulmonary connection. Ann Thorac Surg 2012;93:2028-33. https://doi.org/10.1016/j.athoracsur.2012.02.053

31. Marshall L. Jacobs, Glenn Pelletier, Peter D. Wearden, Victor O. Morell. The role of Fontan's procedure and aortic translocation in the surgical management of patients with discordant atrioventricular connections, interventricular communication, and pulmonary stenosis or atresia. Cardiol Young 2006;16:97-102. https://doi.org/10.1017/S1047951106000813

32. Adatia I, Kothari SS, Feinstein JA. Pulmonary Hypertension Associated With Congenital Heart Disease Pulmonary Vascular Disease: The Global Perspective. Chest 2010;137:5261.

https://doi.org/10.1378/chest.09-2861 